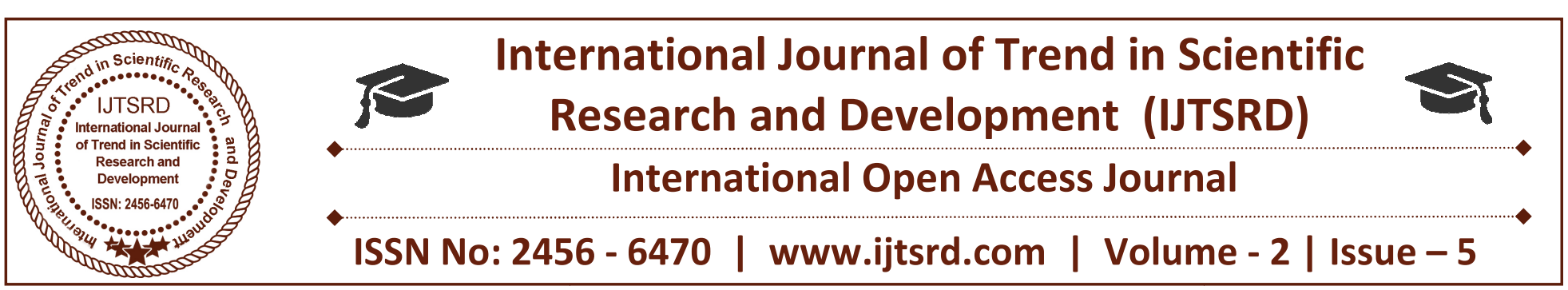

\title{
A Review on GST Execution and its Effects
}

\author{
Amit Ilager \\ Department of Political Science, C. M. Managuli Arts, \\ Science and Commerce College, Sindagi, Karnatka, India
}

\begin{abstract}
:
In today's scenario we pay various taxes i.e. Direct and Indirect taxes, which are felt as burden on us and due to these taxes the corruption is increasing. So, to overcome from all these taxation system the Central Government has decided to make one tax system i.e. Goods and Services Tax (GST). GST is one of the most critical tax reforms in India which has been long awaiting decision. It is a comprehensive tax system that will subsume all indirect taxes of State and central Governments and whole economy into seamless nation in national market. It is expected to remove the burden of existing indirect tax system and play an important role in growth of India. GST includes all Indirect Taxes which will help in growth of economy and proves to be more beneficial than the existing tax system. GST will also help to accelerate the overall Gross Domestic Product (GDP) of the country. GST is now accepted all over the world and countries are using it for sales tax system. This paper will help to show that, what will be the impact of GST after its implementation, difference between present Indirect Taxes and GST and what will be the benefits and challenges of GST after implementation.
\end{abstract}

Keywords: Central, State, Dual, GST, Indirect Tax, Direct Tax, GDP, Implementation.

\section{INTRODUCTION}

India is the hub of taxes where people pay many taxes which create confusion for them. Presently we pay two types of taxes i.e. Direct and Indirect in various sectors. Direct Tax paid directly to the government by the taxpayer i.e. Income Tax, Wealth Tax, and Corporation Tax. Indirect Tax is a tax levied on goods and services rather than on income or profits. It is not directly paid to government but collected from intermediaries (such as retail stores) from the person who bears the ultimate economic burden of the tax (such as consumers). The intermediary later files a tax return and forwards the tax proceeds to government with the return for example Sales Tax, VAT, Excise Duty, and Custom Duty and so on.

GST is a blanket of Indirect Tax that will subsume several indirect state and federal taxes such as Value Added Tax (VAT) and Excise Duty and different State Taxes, Central Surcharges, Entertainment Tax, Luxury Tax and many more. GST was firstly introduced in France in 1954, with introduction of GST France became the first country ever to introduce GST. Its introduction was requiring because very high sales taxes and tariffs encourage cheating and smuggling. After France it was adopted by 165 nations. Now, India is also going to adopt it. After its implementation in India, India will become 166th nation to adopt it In India before 16 years, in 2000 Shri Atal Bihari Vajpy brought this system but no one paid attention on it and due to some reasons it was not passed. On 28th February 2006, the finance minister P. Chidambaram, had announced the target date for implementation of GST on 1 April, 2010. The Constitution (122nd Amendment) Bill was introduced in the Lok Sabha by Finance Minister Arun Jaitely, on 19th December 2014, and passed by the house on 6th May 2015. The bill was passed by Lok Sabha on August 2016. The bill, after ratification by the States, received assent from President Pranab Mukherjee on 8th September 2016. GST bill is brought for the reason that the different taxes paid by us on different rates would be brought under one roof so that all the taxes may get cancelled and only one tax is paid which is GST. Goods and Services Tax (GST) will include one tax one nation; this statement was given by the honorable Prime Minister Mr. Narandra Modi 
of India. In today's scenario we pay $30 \%$ to $35 \%$ tax on different things but with GST it will be only $18 \%$, which shows it will be beneficial and one main thing that GST will remain similar in all nation.

The GST is expected to change the whole scenario of current Indirect Tax. GST will merge all Indirect Taxes under an umbrella and will help in creation of smooth market. Experts say that GST will help in economic growth of the country. It is estimated that GST will help in creation of single, uniform market that will benefit both corporate sector and the Indian economy. Both the State and the Central Government will levy GST on almost all goods and services produced in India orimported into the country. Direct taxes, such as income tax, corporate tax and capital gains tax will not be affected by GST. It will make Indian's tax structure, elaborate and create a similar market across states. GST will replace different Indirect Tax levies i.e. Sales Tax, Service Tax, VAT, Excise Duty, Custom Duty, Countervailing Additional Duty, Special Additional Duty, Securities Transaction Tax, Stamp Duty, Entertainment Tax, Anti-Dumping Duty, Local Body Taxes, Property Tax, Entry Tax, Tax and Duties on electricity, Tax on Goods and Passengers and compliance cost will fall which will lead in getting life simpler. This process will help to increase India's tax- to-gross domestic product ratio. According to experts GST is regarded to increase economic growth by between $0.9 \%$ and $1.7 \%$. Exports are expected to increase economic growth by between $3.2 \%$ and $6.3 \%$, were as imports will likely raise $2.4 \%$ - 4.7\%. GST is a Value Added Tax (VAT) to be implemented in India, from April 01; 2017. Government has promised that GST will reduce the compliance burdens at present. One of the aims of introducing GST is to reduce the cascading effects of taxes which are primary focus of VAT, but VAT system is not comprehensive enough to do so. It would be applicable to all transactions of goods and service. It is to be paid to the accounts of the Centre and the States separately. The rules for taking and utilization of credit for the central GST and the State GST would be aligned. Cross utilization of input tax credit between the Central GST (CGST) and the State GST (SGST) would not be allowed except in case of inter-state supply of goods.
The Centre and the States would have concurrent jurisdiction for the entire value chain and for all taxpayers on the basis of thresholds for goods and services prescribed for the states and the Centre. The taxpayer would need to submit common format for periodical returns, to both the central and to the concerned State GST authorities. Each taxpayer would be allotted a PAN-linked Taxpayer Identification Number (TIN) with a total of 13/15 digits. Till know 22 States ratify GST, which are as follows: Bihar (16 August), Jharkhand (17 August), Himachal Pradesh (22 August), Delhi (24 August), Nagaland (26 August), Maharashtra (29 August), Haryana (29 August), Telangana (30 August), Sikkim (30 August), Mizoram (30 August), Goa (31 August), Odisha (1 September), Pondicherry (2 September), Rajasthan (2 September), Andhra Pradesh (8 September), Arunachal Pradesh (8 September), Meghalaya (9 September), Punjab (12 September) thus it seems that GST will lead to growth in country. Know the question arises why do we need GST? Well while conducting study we concluded that in Indian economy the service sector contributes over $55 \%$, Separate taxation of goods and services is neither viable nor desirable, value added in manufacture and sales of goods require inputs of both - goods and services and vice versa which is often not separable. What is expected to happen next is that with the passage of the GST Bill, the government will have to put up a mad scramble to put together all the mechanism and state approvals in place to implement the GST by its rollout date of April 1, 2017. Additionally, companies and tax collectors will have to be prepared on the necessary changes. Some companies may even have to overhaul their business processes to make way for the new tax change. We all will pay GST on every product or service we buy. Since all Indirect Taxes levied by the states and the centre will be merged into one GST then we would exactly know how much tax we pay which at present is difficult to understand. No distinction would be made between imported and Indian goods and they would be taxed at the same rate. The sellers or service providers collect the tax from their customers. The success of GST would rest upon efficiency, equity and simplicity. 
International Journal of Trend in Scientific Research and Development (IJTSRD) ISSN: 2456-6470

Table 1: Taxes proposed to be subsumed in GST: State and Central Taxes

\begin{tabular}{|c|c|}
\hline STATE TAXES & CENTRAL TAXES \\
\hline Value Added Tax (VAT) & Excise Duty \\
\hline Entertainment Tax levied by states & Additional Excise Duty \\
\hline Luxury Tax & Excise Duty under Medicinal and Toilet Preparation Act. \\
\hline $\begin{array}{c}\text { Tax on Lottery, Betting } \\
\text { and Gambling }\end{array}$ & $\begin{array}{c}\text { Service Tax } \\
\text { Entry Tax other than for } \\
\text { local bodies }\end{array}$ \\
\hline & Duty (CVD), Special Additional Duty(SAD) \\
\hline & Surcharge \\
\hline & CENVAT \\
\hline
\end{tabular}

(Source: Empowered committee of state finance ministers government of India)

\subsection{Need of the study:}

This study will help us to examine the impact of GST after its implementation, it will show the gap between present indirect taxes and GST, \& also the study will show benefits and challenges which GST may face after implementation.

\section{REVIEW OF LITERATURE}

Pinki et al. (2014) studied, "Goods and Service TaxPanacea For Indirect Tax System in India" and concluded that the new NDA government in India is positive towards implementation of GST and it is beneficial for central government, state government and as well as for consumers in long run if its implementation is backed by strong IT infrastructure. Kumar (2014) studied, "Goods and Service Tax - A way forward" and concluded that after implementation of GST in India many indirect tax system will be finished and there will be only one tax i.e. GST which is expected to encourage unbiased tax structure. Sehrawat and Dhanda (2015) studied, "GST in India: A Key Tax Reform" and concluded that due to dissilent environment of India economy, it is demand of time to implement GST. Anushuya and Narwal (2014) studied, "Application of CGE Modals In GST" and concluded that both GST \& CGE are very popular all over the world but GST is a powerful concept in the field of indirect taxes. Chaurasia et al. (2016) Studied, "Role of Goods and Services Tax in the growth of Indian economy" and concluded that in overall GST will be helpful for the development of Indian economy and this will also help in improving the Gross Domestic Products of the country more than two percent.

\section{OBJECTIVES OF THE STUDY}

$>$ To enquire the impact of GST after its implementation.
To find out difference between present indirect taxes and GST.

To identify benefits and challenges of GST after implementation.

\section{RESEARCH METHODOLOGY}

On 7th October 2016 Government of India (GOI) passed Process and Flowchart of GST. Now, GST is going to implement very soon and all the sectors have to register for it. The first step for each sector is to register under Central Goods and Service Tax Act (CGST) and State Goods and Service Tax Act (SGST). If a person is bound to be registered for GST he/she shall register himself under SGST Act of his respective state where he perform his business work he/she shall also register under CGST Act. The Registration of GST is received within 30 days.

The process of registration for GST is different from other registrations in different ways such as:-

1. Permission from CGST and SGST Act for registration is required.

2. If one authority rejects the process for registration there will be automatic rejection by the other authority.

3. There shall be no rejection of application without giving a solid reason to the applicant.

4. Application shall be considered to be granted under CGST/SGST Act if the application for registration has been granted under SGST Act/CGST Act.

5. The non-residential and casual taxable person would also require registration from GST. 


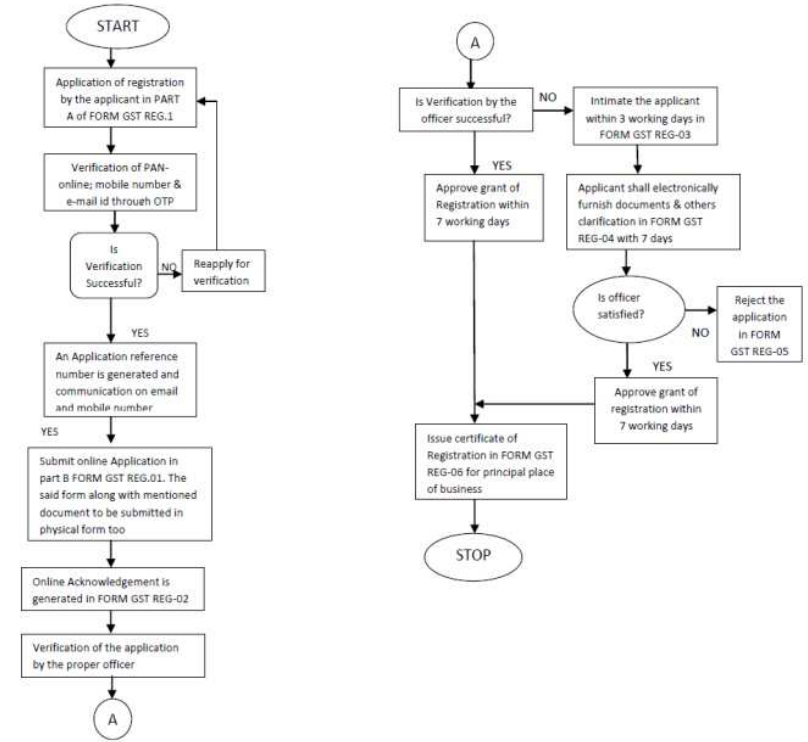

Fig3: Flow chart of registration process of GST

Table 2 reveals that the percentage of taxes before and after implementation of GST, like on package products we pay $4-5 \%$ taxes but after the implementation of GST it would be total $18 \%$, which shows that all package products would turn costly which will affect common man. After package products we see that on readymade garments we also pay $4-5 \%$ of taxes but after GST it will be $18 \%$ so our readymade garments would also be costly like this jewellery, mobile, credit cards etc. would also turn costly but cars, home appliance etc. would be cheaper.
Here we can conclude that after implementation of GST common man will suffer because he would not be able to satisfy his wants completely but there would be no impact on rich people.

Table 2: Tax before and after implementation of GST

\begin{tabular}{|c|c|c|}
\hline GOODS & BEFORE & AFTER \\
\hline Package Products & $4-5 \%$ & $18 \%$ \\
\hline Readymade Garments & $4-5 \%$ & $18 \%$ \\
\hline Jewellery & $3 \%$ & $18 \%$ \\
\hline Mobile \& credit cards & $15 \%$ & $18 \%$ \\
\hline Cars & $30-44 \%$ & $18 \%$ \\
\hline Home appliance & $\begin{array}{l}12.5 \% \text { \& } 14.5 \% \\
\text { (Excise \&VAT) }\end{array}$ & $18 \%$ \\
\hline
\end{tabular}

Table 3 reveals the impact of GST after implementation, it can be understood clearly from the table which shows the rate of goods increasing and decreasing after implementation of GST this table also shows some goods on which there is no implementation of GST. The first row shows the goods whose rate will decrease after GST and second row shows increase in rates of goods after GST. Thus these were some of the items which are affected after the implementation of Goods and Services Tax.

Table 3: Expected price movement for items upon implementation of GST

\begin{tabular}{|c|c|c|}
\hline Decrease & No GST & Increase \\
\hline Television & Bread, white \& whole meal & Mobile phone \\
\hline Refrigerator & Cooking oil(palm oil, coconut oil \& groundnut oil) & Computer \\
\hline $\begin{array}{c}\text { Air- conditioner } \\
\text { pad \& car battery }\end{array}$ & Beef, mutton, lamb, chicken \& pork & Eye-pad\& tablet \\
\hline $\begin{array}{c}\text { Home theater } \\
\text { system }\end{array}$ & Local fruits & Photocopy machine \\
\hline $\begin{array}{c}\text { Hair dryer } \\
\text { Electric fan \& } \\
\text { toaster }\end{array}$ & Diesel & $\begin{array}{c}\text { Digital photo } \\
\text { printing }\end{array}$ \\
\hline $\begin{array}{c}\text { Gas cooker- double } \\
\text { burner }\end{array}$ & Petrol unleaded 95 & $\begin{array}{c}\text { Transportation of } \\
\text { goods }\end{array}$ \\
\hline Electric Iron & Rice & Drinking water \\
\hline Cotton bath towel & Fresh vegetables & Magazines \\
\hline Colour pencil & Fresh fish \&prawans & Fish balls \\
\hline Toothbrush & Powdered milk & Canned sardine \& tuna \\
\hline Dettol, antiseptic & Chicken \& duck eggs & Lipstick \\
\hline Dinning set (6 chairs) & Public transport & Nail colour \\
\hline Diapers & Motor oil & Watches \\
\hline
\end{tabular}


International Journal of Trend in Scientific Research and Development (IJTSRD) ISSN: 2456-6470

\begin{tabular}{|c|c|c|}
\hline Car 850cc & Toll & Cheese \\
\hline Toothpaste & Chilli & Oats \& cereals \\
\hline Plastic mat & Alcohol & $\begin{array}{c}\text { Chilli sauce, oyster } \\
\text { sauce etc }\end{array}$ \\
\hline Imported fruits & Tobacco & - \\
\hline Soft drink & - & - \\
\hline & - & - \\
\hline
\end{tabular}

(Source: http://www.gstindia.com)

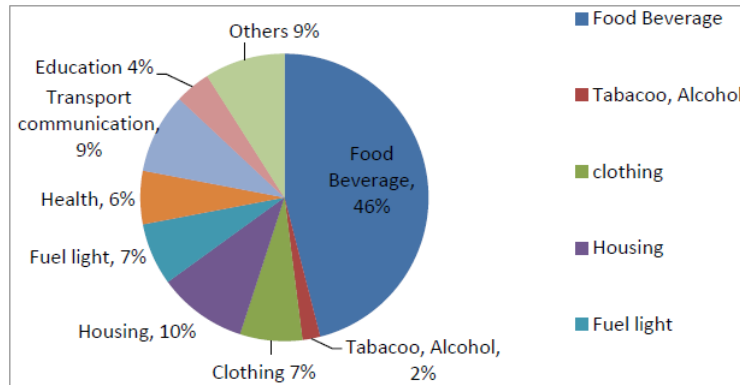

Fig 1: Impact of GST on CPI basket (Source: Edel invest research).

Consumer Price Index (CPI) measures change in price level of a market basket of consumer good and services purchased by households like Food Beverage, Tabacoo, Alcohol, Clothing, Housing, Fuel light etc. The CPI is a statistical estimate constructed using the prices of a sample of representative items whose prices are collected periodically. In this figure we can see sector wise weight age under the current CPI. Figure1 shows that GST will have a significant impact on only $20-25 \%$ items in CPI basket.

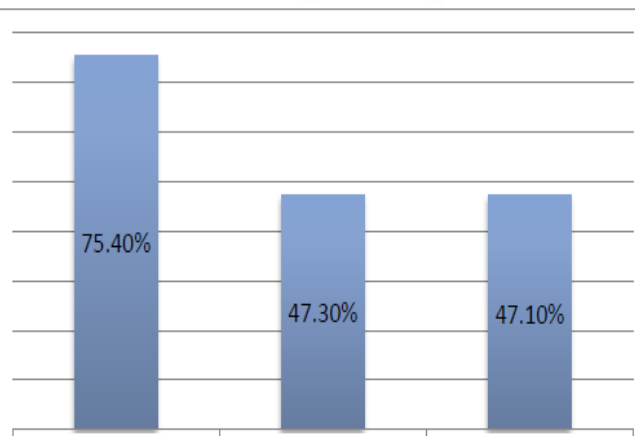

Exempt from Excise Exempt from Sales Tax Exempt from GST*

Fig 2: Impact of GST on excise and sales tax

Figure 2, shows impact of GST on Excise and Sales Tax. Over $50 \%$ of goods under the CPI basket will be exempt from Excise or Sales Tax. In this figure the first bar with $75.4 \%$ is exempt from Excise, the second bar with $47.3 \%$ shows exempt from Sales Tax $\&$ the last bar with $47 \%$ shows exempt of Excise and Sales Tax from GST.

Table 4: Impact of GST in Present

\begin{tabular}{|c|c|c|c|c|}
\hline \multicolumn{5}{|c|}{ Present Scenario After GST } \\
\hline & $\begin{array}{c}\text { With } \\
\text { invoice }\end{array}$ & $\begin{array}{l}\text { Without } \\
\text { invoice }\end{array}$ & $\begin{array}{l}\text { With } \\
\text { invoice }\end{array}$ & $\begin{array}{l}\text { Without } \\
\text { invoice }\end{array}$ \\
\hline Manufacturer to distributor & & & & \\
\hline Sale price of phone & 10,000 & 11,000 & 10,000 & 11,000 \\
\hline $\begin{array}{c}\text { Add: Excise } \\
\text { Duty@12\% }\end{array}$ & 1,200 & - & - & - \\
\hline Add: VAT@4\% & 448 & - & - & - \\
\hline Add:GST@16\% & - & - & 1600 & - \\
\hline Final payment & 11,648 & 11,000 & 11,600 & 11,000 \\
\hline Distributor to wholesaler & & & & \\
\hline Sale price of phone & 15,000 & 15,000 & 15,000 & 15,000 \\
\hline Add:VAT@4\% & 600 & - & - & - \\
\hline Add:GST@16\% & - & - & 2,400 & - \\
\hline Final Receipt & 15,600 & 15,000 & 17,400 & 15,000 \\
\hline Payment of Tax by distributor & 152 & - & 800 & - \\
\hline Net profit to Distributor & & & & \\
\hline Sale price & 15,600 & 15,000 & 17,400 & 15,000 \\
\hline Less: purchase & 11,648 & 11,000 & 11,600 & 11,000 \\
\hline
\end{tabular}


International Journal of Trend in Scientific Research and Development (IJTSRD) ISSN: 2456-6470

\begin{tabular}{|c|c|c|c|c|}
\hline cost & & & & \\
\hline Less: Net tax paid & 152 & - & 800 & - \\
\hline Net profit to distributor & 3,800 & 4,000 & 5,000 & 4,000 \\
\hline Final Result & $\begin{array}{c}\text { Distributor will } \\
\text { prefer } \\
\text { without invoice }\end{array}$ & & $\begin{array}{c}\text { Distributer will } \\
\text { prefer } \\
\text { with invoice }\end{array}$ & \\
\hline
\end{tabular}

(Source: http://www.gstindia.com)

Table 4 divided into two parts in which first part reveals that in present scenario sales price of phone from manufacturer to distributer with invoice is Rs.11, 648 \& without invoice is Rs. 11,000 but after GST the sales price of phone with invoice will is Rs. 11,600 and without invoice is Rs. 11,000.

Second part reveals that sales price of phone in present scenario from distributer to wholesaler with invoice is Rs. 15,600 and without invoice is Rs. 15,000 while as after GST the price of phone with invoice is Rs. 17,400 and without invoice 15,000 . The net profit to distributor with invoice is Rs. 3,800 and without invoice is Rs. 4,000 in present scenario but after GST the net profit of distributor without invoice is Rs. 5,000 and without invoice is Rs. 4,000 thus the conclusion from this table is that in present scenario the distributor will prefer without invoice but after GST the distributor will prefer with invoice.

\section{ANALYSIS/ DISCUSSIONS \\ 5.1 Models of GST:}

There are three prime models of GST, which are available in existing literature which are as follows:-

1. GST at Central (Union) Government Level only

2. GST at State Government Level only

3. GST at both, Union and State Government Levels

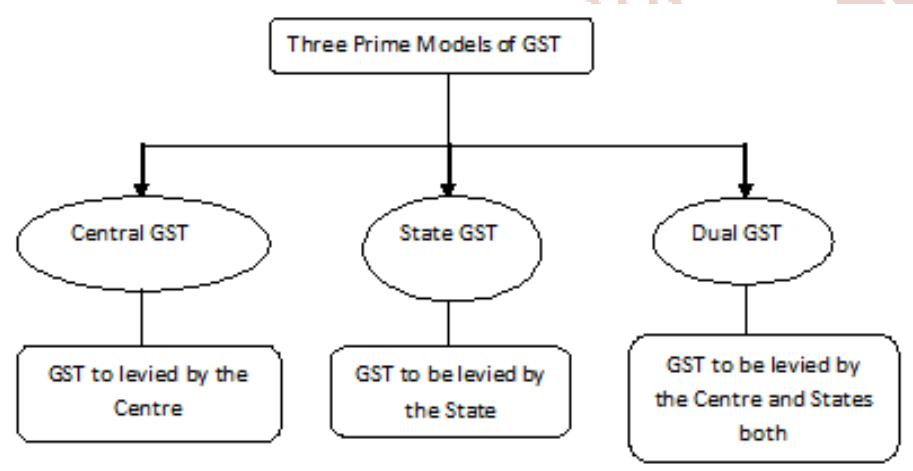

In India the expected model of GST will be "Dual GST" which is combination of both CGST and SGST. All the goods and services bearing certain exemption of taxes will be brought under GST where the difference between the goods and services is ignored.
The important features of Dual GST in India after implementation are as under:-

1. The CGST will be governed by Center and SGST will be governed by State.

2. The VAT system may be replaced by SGST while CENVAT and Service tax may be replaced by CGST.

3. Certain Indirect Taxes subsumed under CGST are Excise duty, Additional Excise Duty, Excise Duty under Medicinal and Toilet Preparation Act, Service Tax, Additional Custom Duty commonly known as Countervailing Duty (CVD), Special Additional Duty (SAD), Surcharge and CENVAT.

4. Taxes subsumed under SGST are Value added tax (VAT), Entertainment Tax levied by State, Luxury Tax, Tax on Lottery, Betting and Gambling, Entry Tax other than for Local bodies.

5. 5. The rates of different goods and services may separately be decided by CGST and SGST keeping in view the burden of different taxes, capability of common man to pay tax etc.

6. Certain products are excluded from GST like Petroleum, Liquor and Tobacco.

7. With CGST and SGST exports of goods will be zero rated.

8. Taxes which are collected by local bodies are not subsumed in GST system.

The cross utilization of inputs between CGST and SGST is not allowed which means inputs of central GST can be utilized only for the payment of CGST and inputs of state can be utilized only for the payment of state. (Source: - Hindu Business Line, dated 30-06-2009)

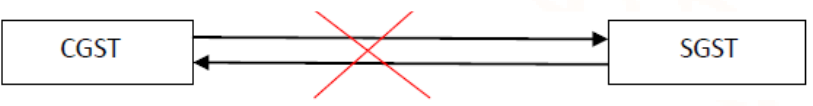

Cross-utilization for payment of CGST and SGST is not allowed.

\subsection{Importance of GST to the economy:}

GST is designed to remove the burden by ending many Indirect Taxes. GST will be important for 
economy in following ways like GST will reduce tax evasions, it will help to provide more money to backward states like Bihar, Jharkhand etc. which will improve the economy of the country it will also help in removal of local tax BIAS which means a person can set his factory in any state without worrying about different tax systems. In conclusion we can say that GST is one tax that can be a major breakthrough in India taxation system.

\subsection{GST will positively impact the common man} in many ways:

GST is a unified tax system removing bundle of Indirect Tax like VAT, CST, Service Tax, CAD, $\mathrm{SAD}$, and Excise Duty which will have a positive impact on common man. There will be less tax compliance and a simplified tax policy as compared to earlier tax structure, GST will reduce the cascading effect of taxes i.e. tax on tax system, It will help in removing the manufacturing cost which will bring price of consumer goods down, the lower price will further lead to an increase in demand/consumption of goods, increased demand will lead to increase supply hence this will ultimately lead to rise in production of goods. The increased production will lead to more job opportunities. GST will crub circulation of black money. Thus GST will have a positive impact on common man in many ways.

\subsection{Problems which GST might face after implementation:}

Disputes are likely to arise between Centre and State over tax. Highly sophisticated IT infrastructure is required, issue of taxing e-commerce is to be appropriately addressed and integrated and some political imbalance. Some challenges for the implementation of GST will be: The bill is yet to be tabled and passed in the parliament. To implement the bill there has to be lot changes at administration level, information technology integration has to happen and sound IT infrastructure is needed. The state governments have to be compensated for the loss of revenues (if any). GST being consumption - based tax. States with higher consumptions of goods and services will have better revenues so co-operations from state governments would be one of the key factors for successful implementation of GST.

\subsection{Place of supply rules:}

1. In the case of a sale of real property, the place of supply is the jurisdiction in which the property is located. Similarly, services directly connected with real property (i.e., services provided by real estate agents or architects) are also taxed in the place in which the property is located.

2. In the case of mobile services (that is, passenger travel services, freight transportation services, telecommunication services, motor vehicles lease/rentals and E-commerce supplies), there is no fixed place of performance or use/enjoyment of the service. Therefore special rules need to be framed keeping in mind the basic destination principle.

3. In the case of other services and intangible property, the place of supply is determined on the basis of one or more of the following proxies: Place of performance of service, Place of use or enjoyment of the service or intangible property, Place of location/residence of the recipient; and Place of location/residence of the supplier.

\subsection{Treatment of different areas after implementation of GST:}

How GST will affect the different areas of goods and services are shown as under:-

\subsubsection{Treatment of capital Goods:}

Full and instant input credit would be allowed for tax paid by both CGST and SGST on all purchases of capital goods in which GST would be included.

\subsubsection{Treatment of petroleum products:}

To stop the negative externality of petroleum products which is used for consumption must be checked. The full range of petroleum products is made with combination of multiple taxes by both central level and state level which leads to burden and hence with GST there will be one tax system and cascading effects would be reduced.

\subsubsection{Treatment of the power sector:}

SGST should subsume the electricity duty levied by state. Article 278 and Article 288 of the Constitution should be amended to enable levy of GST on supply of electricity to Government at all levels like any other normal goods. The tax system for the power sector should be same as in case of any other normal goods. GST will help to reduce the cost of power projects and similarly the generation and distribution, which will lead to increase the profitability for the country. Thus GST is very important in power sector.

\subsubsection{Treatment of Transport service:}

GST would subsume all taxes on vehicles and tax 
on goods and passengers levied by the state government. All the equipment which are used in transportation, all services of transportations like railways, air road and sea must form an important of GST where both Central and State have concurrent jurisdiction. The tax regime of transportation will be same as in other normal goods.

\subsubsection{Treatment of Financial services:}

In financial service there are three exemption methods for financial services i.e. the exemption method, the zero rating method and full taxation method. The exemption method and zero rating method reduces the potential GST base also distorts consumption while as full taxation method significantly enhance the tax base and result in equal treatment of all services. Thus financial services should be taxed on the bases of full taxation method.

\subsubsection{Treatment of Small Scale Industries (SSI):}

The Small Scale Industries generally deal with various types of taxes therefore in order to reduce the burden from these industries one tax system is made i.e. GST in which CGST and SGST would talk and take an important decision about the taxing system of Small Scale Industries.

\subsection{Latest updates for the implementation of GST in India:}

There are some updations for implementation of GST in India, are as follows:

1. On 12th September Punjab is likely to become twenty second state to clear the constitutional amendment before it heads for presidential asset. The bill was first cleared by BJP-ruled Assam on August 12, followed by Bihar, Jharkhand, Chhattisgarh, Gujarat, and Himachal Pradesh.

2. The Integrated GST (IGST) \& Central GST (CGST) laws would then be approved by the union cabinet and then are likely to be sending to parliament for its approval in the winter session with the deadline of April 1, 2017 for Indirect Tax regime.

3. President Pranab Mukherjee signed the Goods and Service Tax Bill (GST), making the bill in the form of a law. The constitutional amendment bill proposing the indirect tax regime was already approved by Lok Sabha, Rajya Sabha, and over 16 state assemblies. Under GST, taxes previously imposed by the Centre and States will be replaced with a common nation- wide taxation system.
4. GST comes in way of governments plan to scrap old vehicles.

5. GST Council gets cabinet approval, the council to be headed by finance minister Arun Jaitely and comprising of representative of all 29 States and two union territories, the cabinet headed by P.M. Mr. Narendra Modi approved the process, formation of GST council.

\section{CONCLUSION}

The GST System is basically structured to simplify current Indirect Tax system in India. A well designed GST is an attractive method to get rid of deformation of the existing process of multiple taxation also government has promised that GST will reduce the compliance burden at present there will be no distinction between imported and Indian goods \& they would be taxed at the same rate. Many Indirect Taxes like Sales Tax, VAT etc., will be finished because there will be one tax system i.e. GST, that will reduce compliance present burden. GST will face many challenges after its implementation and will result to give many benefits. In overall through this study we conclude that GST play a dynamic role in the growth and development of our country.

\section{REFERENCES}

1. Pinki, Supriya Kamna, RichaVerma (2014), "Good and Service Tax: Panacea For Indirect Tax System In India”, "Tactful Management Research Journal”, vol.2, Issue 10, July2014

2. N. Kumar (2014): "Goods and service tax in India- A way forward", "Global Journals of multidisciplinary studies", vol.3, issue 6, may

3. P. chaurasia, S. Singh, P. Kumar Sen (2016), “ Role of Goods and Service Tax in the growth of Indian economy", " International journal of science technology and management", vol.5, issue 2, February 2016.

4. M. Sehrawat, U. Dhanda (2015), "GST in India: A key tax reform", "International journal of research granthaalayah", vol.3, issue 12, December 2015.

5. http://www.economictimes.com

6. Reference on Goods \& Services Tax by ICSI

7. .http://www.gstindia.com

8. http://www.gstseva.com

9. http://empcom.gov. 
International Journal of Trend in Scientific Research and Development (IJTSRD) ISSN: 2456-6470

10. http://economictimes.indiatimes.com

11. http:// www.taxguru.in

12. Hindu Business Line

13. Custom department

14. Empowered committee of state finance ministers government of India
15. https://www.google.co.in/search?q=images+of+ effects+of+GST.

16. http://www.vatlive.com/vat-rates/internationalvat-and-gst-rates/

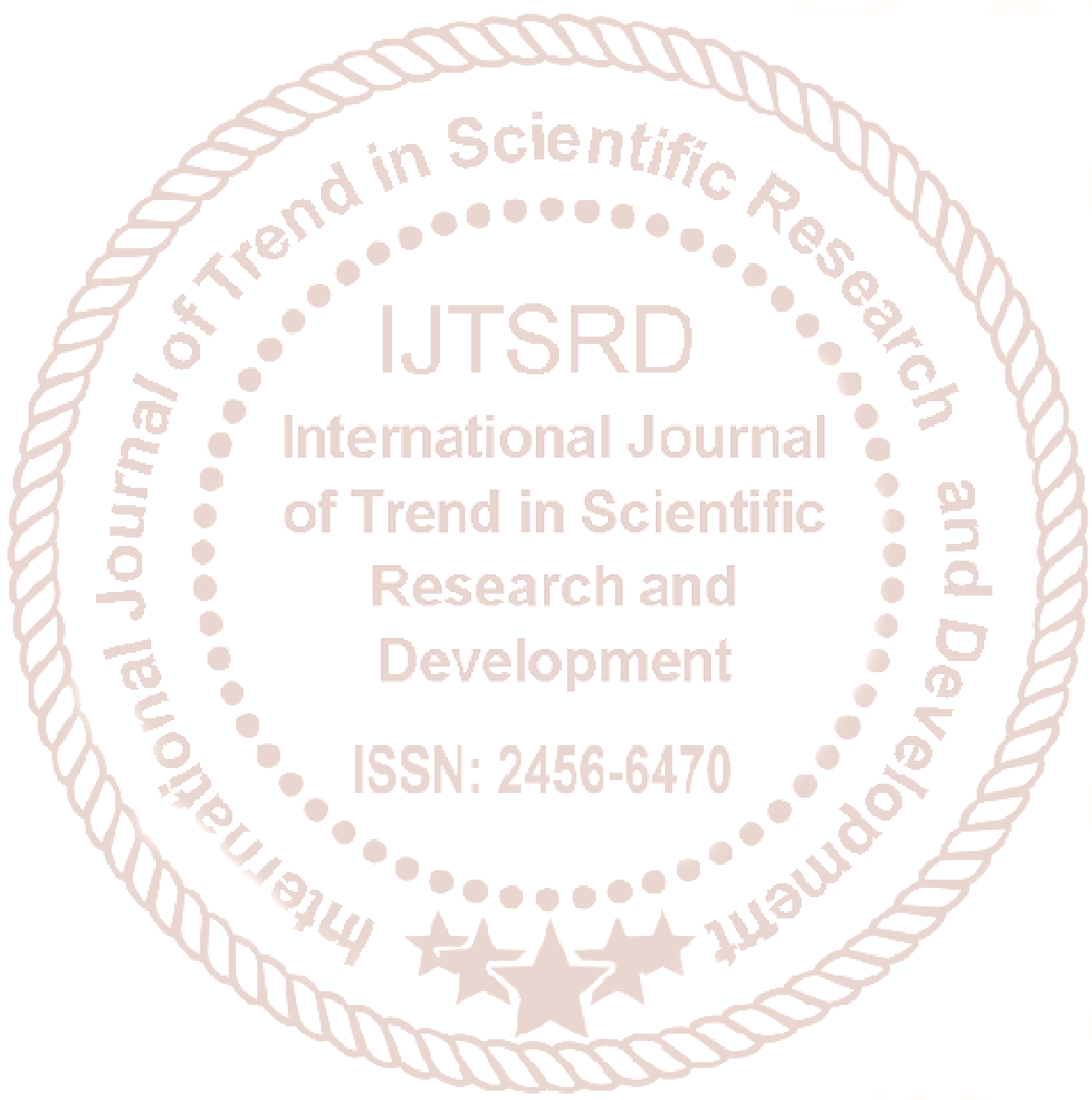

